\title{
オフィスワーカーが休䡯のために訪れる屋上の現状と 屋上緑化の今後のあり方
}

\section{Questionnaire Study on Actual Situation and Future of Green Roofs Used as Office Worker's Relaxation Spaces}

\author{
木野村泰子* 下村＼cjkstart孝** \\ Yasuko KINOMURA Takashi SHIMOMURA
}

\begin{abstract}
The questionnaire survey was done among employee in business buildings with or without a garden on its rooftop to clarify the actual conditions and the evaluation of the roofs as spaces for relaxation or for lunch break. The ratio of the respondents who took rest in the roof gardens at lunch time was significantly higher when that roof garden received a higher evaluation. In addition, $68 \%$ of respondents answered that they wanted to take rests in the green roof when they felt the sense of relief and also the $39 \%$ the sense of season. On the other hand, $65.0 \%$ of the respondents who did not intend to take rest in the green roof said that there was no place or facility to sit down on. And the $43 \%$ answered there was a little shade and also the $38 \%$ remarked that they couldn't be bothered to go up to the roof. Results showed that the green roofs are evaluated by the office workers as spaces for relaxation and lunch breaks when they were able to feel comfort, nature and the change of the season on them. And it was also shown that above-mentioned preferable conditions would be maintained by introducing some facilities such as benches, rain covers, pergolas and the vegetations consisting of various kinds of plants such as grass, flowers, and evergreen shrubs.
\end{abstract}

Keywords: office worker, roof garden, relaxation space, bench, chair, shade キーワード：オフィスワーカー，屋上庭園，休㮩場所，ベンチ，椅子，日陰

\section{1. 研究の背景と目的}

地上の緑化可能地が減少した都市での緑化対象として, 建築物 の屋上が注目されている ${ }^{1}$ 。東京都では，2001 年の自然の保護と 回復に関する条例改正に基づき, 一定規模以上の敷地を有する建 築物に屋上緑化を義務付けている ${ }^{2)}$ 。その後，2002 年に兵庫県 ${ }^{2)}$, 2006 年に大阪府 ${ }^{2}$ で, さらに, 京都府 $\left(2007\right.$ 年 4 月 ${ }^{3)}$ も屋上緑 化を含む建築物の緑化を義務付けており, 今後も, 屋上緑化を義 務付ける自治体は増えると考えられる。

屋上緑化には，ヒートアイランド現象緩和，雨水の一次貯留， 生態系の創出, 景観の向上および心理的効果など多面的・複合的 な意義が認められる ${ }^{1)}{ }^{4)-7)}$ が, これまで, 屋上緑化推進の主な 目的がヒートアイランド現象の緩和に集中しているように思われ， この機能のみに特化した屋上緑化の普及を懸念する意見 ${ }^{4)}$ ある。 2003 年に，日本全国の主要な屋上緑化 149 事例を対象に行っ たアンケート調査では，屋上を緑化している民間の建築物の数は， 企業ビルが最も多く, 施工の目的と, 期待する効果は䕀いと景観 であった (佐々木, 未発表)。また, 企業ビルの屋上緑化利用者 を対象として行ったアンケート調査 (佐々木, 未発表) では, 休 㓤や気分転換を目的に利用する人が多いことが示された。

労働安全衛生法は, 快適な職場環境の形成のために, 労働者の 疲労を回復するための施設又は設備の設置又は整備に努めること を義務付けている ${ }^{8)}$ 。また, 事業者が講ずべき快適な職場環境の 形成のための措置に関する指針 $\left.{ }^{9}\right)$ では, 休䕀室や相談室, シャワー 室, 運動施設, および敷地内に緑地を設けることとしている。し かし, オフィスワーカーを対象にしたアンケート調査では, オフィ スのリフレッシュスペースなどに不満を持つ人は多く ${ }^{10)}$ 疲労やス トレス解消のためのアトリウム ${ }^{11)}$ や開放感や居心地の良さの感じ られるリフレッシュ空間 ${ }^{12)}$ の設置が職場に求められている。

緑化された屋上の植物と開放感が，「楽しい」,「気持ちが良い」, 「好ましい」,「安らぐ」などの心理的評価を高めることが明らか

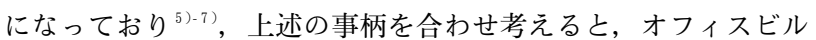

の屋上を緑化することにより，そこで働く人々に身近な居心地の 良いリフレッシュ空間を提供する事ができるのではないかと推測 できる。

そこで, 本研究では屋上緑化を, 都市で働くオフィスワーカー に安らぎとくつろぎのための休暞場所を提供する手法と想定して, 緑化された屋上を持つオフィスビルの休螅施設の実態及びオフィ スワーカーの休媳時間利用の実態を把握した。さらに，屋上が緑 化されていないオフィスビルで働くオフィスワーカーにも同様の 調査を行い，それらの結果を比較することで, 緑化された屋上の 休㮩場所としての可能性と課題を把握し, 望ましい屋上緑化のあ り方を考察した。

\section{2. 研究方法}

（1）屋上が緑化されたオフィスビルの休䕀施設と屋上緑化の実 態の把握

調査対象は，京都市，大阪市，神戸市の 3 階建て以上のオフィ スビルと, 事務所を併設する工場や研究所などのうち， 2 階より 上の階で人の出入りが可能な屋上に植栽を施した建築物とした。 佐々木ら ${ }^{5)}$ が調査対象とした 6 事例に加え, 緑化関連業界の新聞, 雑誌やインターネット上の検索エンジンを用いた佐々木ら ${ }^{5)}$ の方 法に準じて新たに抽出した屋上緑化新設事例の中から，対象とな るオフィスビルを 26 事例抽出した。これらを合わせた 32 事例に 対し, 2006 年 5 月から 6 月にかけて現地調査への協力依頼を行 い，応諾を得た 17 事例について，5月から 7 月にかけて施工の 目的や社員の休馣時間の過ごし方などを訊ねるヒアリング調査と, 屋内の休䕀施設及び屋上に設置されている休息施設の有無などを 把握する現地調査を行った。

（2）屋上が緑化されたオフィスビルで働くオフィスワーカーへ のアンケート調査

現地実態調査を行った 17 事例の内, 担当者から承諾を得た 7 事例で，在籍するオフィスワーカーを対象にアンケート調查を行っ

“株式会社ヨードクリーン **京都府立大学人間環境学部環境デザイン学科 
た。また，これまでに報告された屋上評価の成果を参考にして， 以下に述べ方法で, 各事例の緑化された屋上を休㕷場所として 客観的に評価することを試みた。

屋上の景観を評価する際に考慮する必要があると指摘されてい る, 屋上の面積 ${ }^{5)-7)}$, 植栽面積比率 ${ }^{5)}$, 周辺の人工物の有無 ${ }^{5)-6)}$ および植栽植物種数 ${ }^{5)}$ はいずれも 0 〜 の 6 段階, 植物の高さ 7 は印象が良いとされる中・高木がある場合を 2 , 地被植物及び低 木がある場合を 1 の 2 段階, 休㲡施設 ${ }^{13)}$ の有無を, 座れる場所 ${ }^{14}$ は 0 〜 56 段階, テーブルや日よけは無しを 0 , 有りは台数を 数值化し,休䡯時間の過ごし方では飲食の回答が多い212)ことから 飲食の可を 1 , 否を 0 とそれぞれ数值化して, これらの評価得点 を合計して対象ビルの評価得点とした。対象とした事例に複数企 業が入居している場合は, テナント会社に在籍するオフィスワー カーへの協力も依頼したため, 調査対象者はビル 7 事例に勤務す る計 11 社のオフィスワーカーとなった。

調査期間は, 2006 年 7 月 19 日から 8 月 3 日にかけて, 各事例 の社内担当者宛にアンケート調査用紙を郵送し, 配布日から 2 週 間以内に回収および返送された回答用紙を分析対象とした。

調査内容は, 回答者の属性（性別, 年代, 所属部門と喫煙の習 慣の有無）のほか, 屋上緑化の認知ときっかけ, 昼休㮩時とリフ レッシュ休䕀時の屋上緑化の利用経験と過ごし方, 利用する理由, 普段各休数時間を過ごす場所での過ごし方やその場所を選ぶ理由 と今後の屋上緑化の利用意思とその理由についての各質問項目を 設定した。回答のために設定した選択肢は, 各事例の休䕀施設や 緑化された屋上の実態および利用規則などに即したものを用いた ため，アンケート調査用紙の同じ設問に用いた選択肢が，事例に より一部異なっている。そのため, 各選択肢ごとにそれを用いた 事例の有効回答数の合計を母数として, 結果を分析した。

（3）屋上が緑化されていないオフィスビルで働くオフィスワー カーへのアンケート調査

調查対象は, 主要なオフィスビルのうち, 2 階より上の階で人 の出入りが可能な屋上に, 植栽を施していないオフィスビルで働 くオフィスワーカーとして調査対象ビルを探索した。

上記（2）の調査で対象となった事例には地球環境や地域環境, 社員の働く環境への配慮を $\mathrm{PR}$ する企業の自社ビル・本社ビルが 多く含まれていた。そこで，2006 年 10 月 25 日までに，これら アンケート調查対象とした事例周辺に本社・本社ビルを持つ企業 を会社四季報 ${ }^{15)}$ から 200 事例抽出した。企業ホームページにおい て, 地球環境から社員の働く環境への配慮を環境方針として揭げ ていることなどを確認し抽出した 59 事例に対して, 社員への屋 上開放の実態を電話で問い合わせた。屋上を開放し ているビルに対し，在籍するオフィスワーカーへの アンケート調査への協力と，屋上を開放している理 由などを訊ねるヒアリング調査, 屋上に設置されて いる設備などを調べる現地調査への協力を依頼した。 屋上を開放しており，さらに，調査への協力を得ら れたビルは限定されており，対象を見いだすのに困 難が伴った。その結果，積極的にではないが屋上を 開放しており，オフィスワーカーの出入りが可能な 4 事例と, 屋上緑化施工を計画している 1 事例を見 出し, 計 5 事例でアンケート調査への協力に承諾を 得た。調査対象者はこれら 5 事例のビル内に在籍す る計 6 社のオフィスワーカーとした。

2006 年 10 月 26 日から 11 月 6 日にかけて, 各事 例の社内担当者宛にアンケート調査用紙を郵送し， 配布日から 2 週間以内に回収できた回答用紙を郵送 により入手し，分析に供した。

調査内容は，回答者の属性（性別，年代，所属部
社員の想いの場

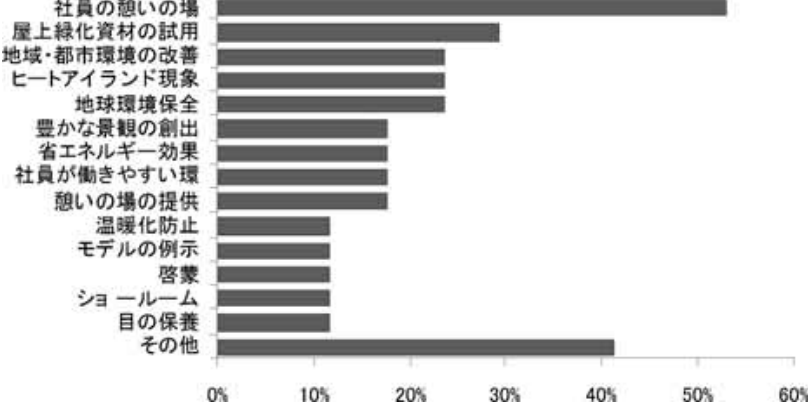

図-1 屋上緑化施工の目的 $(n=17$ ，複数回答 $)$

門および喫煙の習慣の有無）のほか，屋上の利用経験の有無とそ の目的, 屋上緑化の認知之, 屋上が緑化されたと仮定した場合の 休㮩場所としての利用意思とその理由, 望ましい緑化形態と必要 な施設・設備，および過ごし方についての各項目とした。

\section{3. 結果と考察}

（1）屋上が緑化されたオフィスビルの休䕀施設

(i) 緑化の目的

屋上を緑化した目的は社員の硨いの場（52.9\%）が最も多く, 次いで屋上緑化資材の試用・実験（29.4\%）となり，そのほかに も 12 項目があげられ，多岐にわたっていた（図－1）。

(ii ) 休熄施設の実態

屋上に設置されている休息施設を，企業ビルの屋上緑化利用者 を対象として行った佐々木のアンケート調查 (未発表) で要望の 高かった椅子, 日よけ, テーブル, 雨よけ, 灰皿・ゴミ箱および 自動販売機に分類した。椅子やベンチなどの他に，植栽の縁など 座るのに抵抗が無いと判断した場所を座れる場所, 藤棚とパラソ ルなどを日よけ，およびパラソルなどを雨よけと定義した。これ らの内設置の最も多い休鄎施設は, 座れる場所の $70.6 \%$ あっ たが，椅子やベンチが一定数設置されている事例は $58.8 \%$ とな り，日よけなどは $30 \%$ 以下と少なかった（図－2）。

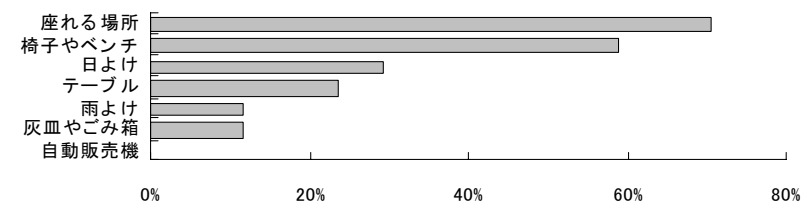

図－２屋上緑化に設置されている休秘施設（ $n=17$ ，複数回答 $)$

\begin{tabular}{|c|c|c|c|c|c|c|c|c|c|c|c|c|c|c|}
\hline \multirow{2}{*}{ 事例名 } & \multicolumn{2}{|c|}{ A } & \multicolumn{2}{|c|}{ B } & & c & \multicolumn{2}{|c|}{ D } & \multicolumn{2}{|c|}{ E } & \multicolumn{2}{|c|}{$\mathrm{F}$} & & G \\
\hline & & 点数 & & 点数 & & 点数 & & 点数 & & 点数 & & 点数 & & 点数 \\
\hline 屋上面積( $\left(\mathrm{m}^{2}\right)$ & 150 & 0 & 560 & 1 & 500 & 1 & 1919 & 5 & 100 & 0 & 820 & 2 & 140 & 0 \\
\hline 植栽面積比 & 0.5 & 2 & 0.6 & 3 & 0.3 & 2 & 1.0 & 5 & 0.4 & 2 & 0.5 & 3 & 0.5 & 3 \\
\hline 周辺の人工物 & 1面 & 4 & 1面 & 4 & 1面 & 4 & 2面 & 3 & 3面 & 2 & 1 面 & 4 & 0 面 & 5 \\
\hline 植物の種類（種） & 14 & 1 & 12 & 1 & 51 & 5 & 41 & 4 & 2 & 0 & 3 & 0 & 31 & 3 \\
\hline 地被植物 & 0 & 1 & 0 & 1 & 0 & 1 & 0 & 1 & 0 & 1 & 0 & 1 & 0 & 1 \\
\hline 低木 & 0 & 1 & 0 & 1 & 0 & 1 & 0 & 1 & - & 0 & - & 0 & 0 & 1 \\
\hline 中木·高木 & 0 & 2 & 0 & 2 & 0 & 2 & 0 & 2 & 0 & 2 & - & 0 & 0 & 2 \\
\hline 座るところ(個) & 16 & 5 & 0 & 0 & 1 & 1 & 9 & 3 & 1 & 1 & 1 & 1 & 0 & 0 \\
\hline テーブル(台) & 2 & 2 & 0 & 0 & 1 & 1 & 1 & 1 & 1 & 1 & 1 & 1 & 0 & 0 \\
\hline ひよけ (台) & 0 & 0 & 0 & 0 & 1 & 1 & 2 & 2 & 1 & 1 & 1 & 1 & 0 & 0 \\
\hline 喫食 & 不可 & 0 & 可 & 1 & 可 & 1 & 不可 & 0 & 不可 & 0 & 可 & 1 & 可 & 1 \\
\hline 喫飲 & 可 & 1 & 可 & 1 & 可 & 1 & 不可 & 0 & 不可 & 0 & 可 & 1 & 可 & 1 \\
\hline 合計点数 & & & & 15 & & 1 & & & & & & 13 & & 7 \\
\hline
\end{tabular}


(iii）屋上の評価

各事例の屋上緑化評価得点を表- 1 に示す。得点が高かったの は D の 27 点, C の 21 点であった。いずれの事例も社員の働く 環境への配慮を目的として施工されており, 面積が広く, 休鄎施 設も充実していた。一方, 最も得点の低かった Eでは, 休慜場 所としての利用を目的として施工されていたが, ベンチなどの休 鄎施設を設置できないほど面積が狭く，植栽植物種数が少なかっ たことが影響していると推測された。

（2）屋上が緑化されたオフィスビルでのアンケート調査

（i）回答者の属性

配布した 730 部のうち，504 部の有効回答を得た（有効回答率 69.0\%)。回答者は, 男性が 348 名で $69.0 \%$ を占めた。また, 年 齢では, 30 代が 168 名 (33.3\%) で最も多く, 次いで 50 代 (124 名, 24.6\%)，40 代 (118 名, 23.4 $\%), 20$ 代 (66 名, 13.1\%) であり, 60 代以上 $(4.6 \%), 10$ 代 $(0.6 \%)$ および無回答 $(0.4 \%)$ は少数であっ た。さらに喫煙習慣のある回答者は 504 名中 137 名 (27.2\%) であった (以上，いずれも図表省略)。所属部 門は，総務・経理・人事が $28.2 \%$, 営業・販売 $24.2 \%$, 設計・技術 21 . $8 \%$ となり (表一 2 ), 時間管理は各 自に任されている ${ }^{16)}$ 回答者が多かった。

\begin{tabular}{|c|c|c|}
\hline 回答者の所属部門 & 人数 & $\%$ \\
\hline 総務·経理·人事 & 142 & 28.2 \\
\hline 営 業·販 売 & 122 & 24.2 \\
\hline 設計·技術 & 110 & 21.8 \\
\hline 生産管理·製造管理 & 26 & 5.2 \\
\hline 企画·計画 & 17 & 3.4 \\
\hline 資材·調達·購買 & 8 & 1.6 \\
\hline 研究·開発 & 6 & 1.2 \\
\hline その他 & 51 & 10.1 \\
\hline 無回答 & 22 & 4.4 \\
\hline 総計 & 504 & 100.0 \\
\hline
\end{tabular}

（ii）屋上緑化の認知度とそのきっかけ

屋上緑化の認知度は $92.5 \%$ であった (図表省略)。複数企業が 入居している事例では, テナント会社従業員の認知度が低くなっ た。認知のきっかけは「同僚・上司から聞いて」が $39.3 \%$ と最 も多く(図-3), テナント会社では, 社員への屋上緑化の情報 提供が不十分であったのではないかと推測される。

（iii）休磒時間の過ごし方

昼休笪時間では，男性は，自席 (44.0\%) を最むよく利用する 回答者が多く (図-4), 利用する理由 (図-5) は, 他者への 気兼齐が無い (61.5\%)，座れる場所が十分である (43.7\%) が 高い值を示し，過ごし方（図－6）はインターネット (48.9\%), 昼寝・仮眠 (46.0\%) 扔よび，ぼーっとする (37.4\%) などが高 い值を示した。一方，女性は食堂・喫茶室（29.1\%）を利用する 回答者が最も多く（図-4), 利用する理由（図－5）は，座れ る場所（61.8\%）とテーブル（32.4\%）が十分にあることが高い 值を示し, 過ごし方 $($ 図－6）は会話・雑談 $(80.0 \%)$, 食べ物 を食べる（51.4\%）などが高い值を示した。ヒアリング調査にお

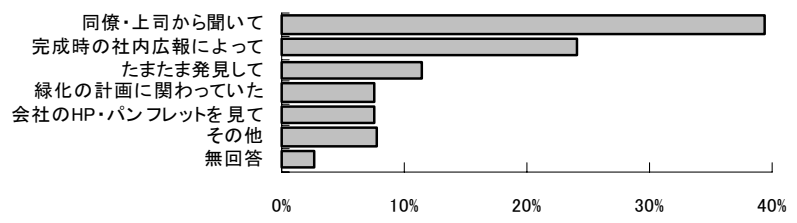

図一 3 屋上緑化認知のきっかけ $(\mathrm{n}=466)$

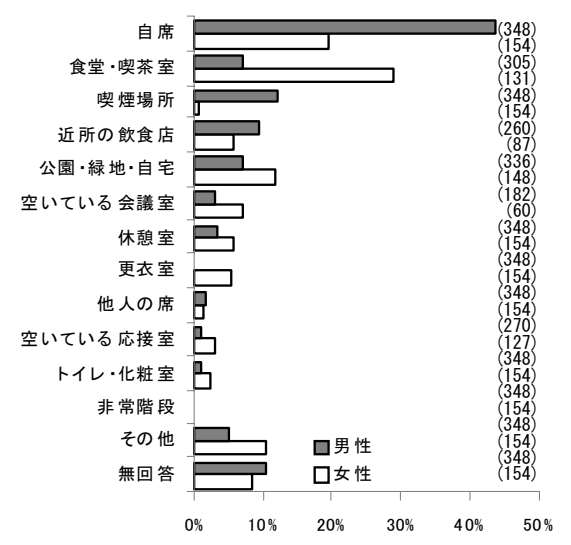

図－4 男女別昼休息時間に最もよく利用 する場所（3つまで選択）（図中 （ ）内の数值は回答数）

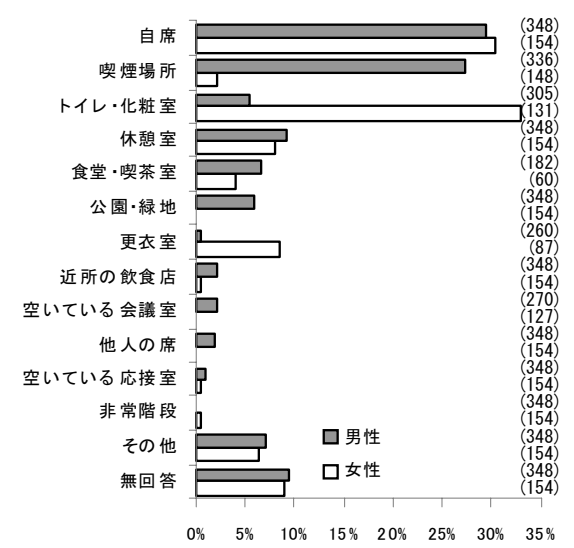

図－７男女別リフレッシュ休㮩時間に最 もよく利用する場所（3つまで選 択）(図中（）内の数値は回答数）

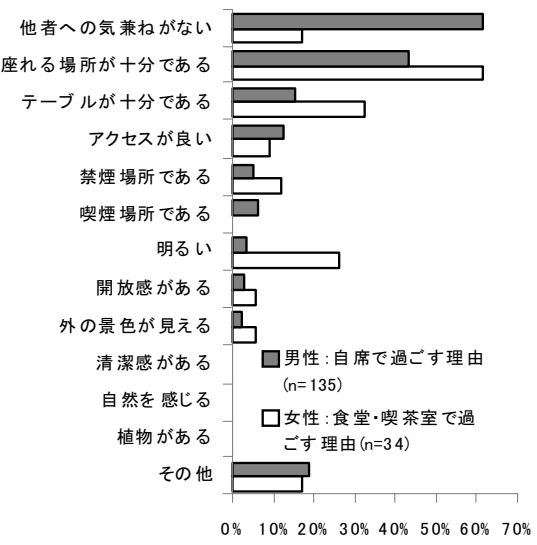

図－ 5 男女別最もよく利用する場所で昼 休䡯時間を過ごす理由（ 3 つまで 選択）

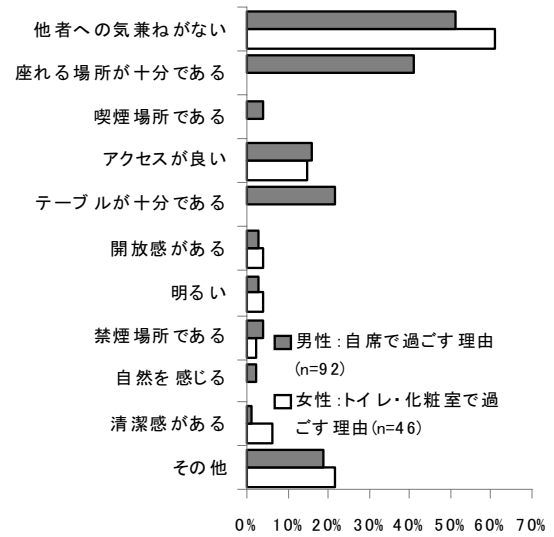

図－８男女別最もよく利用する場所でリ フレッシュ休鄎時間を過ごす理由 （3つまで選択）

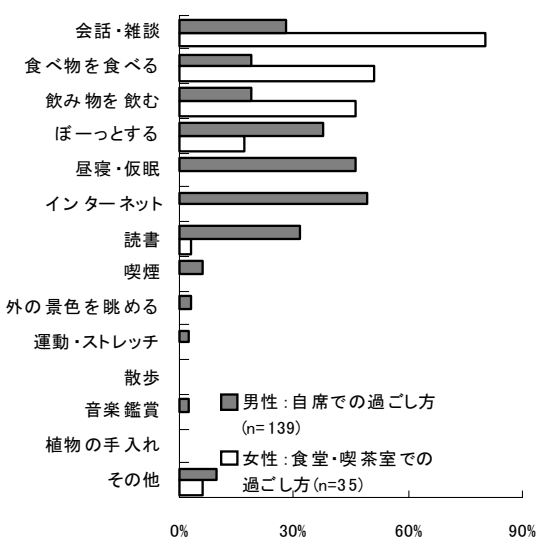

図-6 男女別最もよく利用する場所での 昼休䕀時間の過ごし方（ 3 つまで 選択）

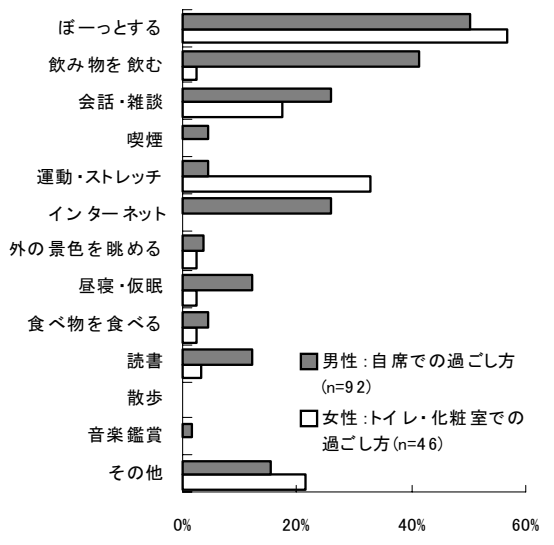

図-9 男女別最もよく利用する場所での リフレッシュ休秘時間の過ごし方 （3つまで選択） 
いても, 男性は自席に一人で, 女性は空いている部屋などに複数 名集まって，昼休㕷時間を過ごしているとの回答が得られており， 同様の傾向を示した。

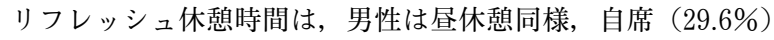
を最もよく利用し (図一 7), その理由 (図-8) は, 他者への 気兼ねが無い $(51.1 \%)$ ことが高い值を示し，過ごし方（図-9） はぼーっとする (50.0\%), 飲み物を飲む (41.3\%) などの值が 高かった。一方女性は, トイレ・化粧室（33.1\%）を最むよく利 用し (図-7), 利用する理由 (図-8) は, 他者への気兼ねが 無い (60.9\%) が高い值を示し, 過ごし方（図－9）はぼーっと する $(56.5 \%)$ ，運動・ストレッチ (32.6\%) などの順となった。 その他，僅かながら，男女共に昼休款時間も仕事をしているとい う回答や，時間が定められていないリフレッシュ休欯は，全く取 ることができていないという回答もあり, 㛜しい状況が窥えた。 また, 最もよく利用する休鄎場所を問う設問に, 緑化された屋上 の回答は得られなかった。ヒアリング調査においても, いずれの 事例からも, 利用者は少ないとの回答が得られており, 社員の頽 いの場を目的として施工されていても，あまり活用されていない ことが推測される。

大山年 ${ }^{21}$ ，オフィスワーカーが利用しにくいと感じていても， リフレッシュ休覕を自席やトイレで取らざるを得ない現状を明ら かにし，「他にくつろげる場所がない」という消極的な理由から，

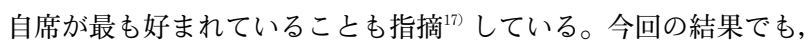
休㦝室など, オフィスビル内に設けられている休覟のための部屋 を利用する回答者の割合は低く, また, 各休鄎時間を自席やトイ レで過ごす理由として他者への気兼ねが無いことが高い割合を示 しており, 利用しやすい, 快適な休喤場所が不足していることが 示唆された。

すでに, 安静状態での休息に比べ, 散歩 ${ }^{18)}$ やエアロバイク運 動 $^{19)}$ など, 運動休息後の疲労回復効果が高いことが明らかにされ

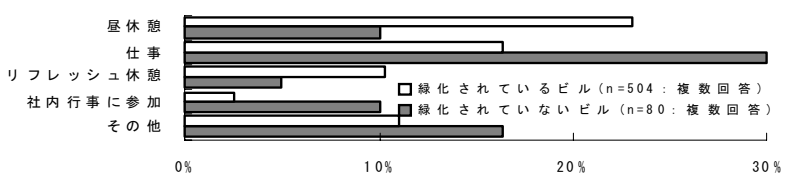

図一10 屋上を訪れる目的

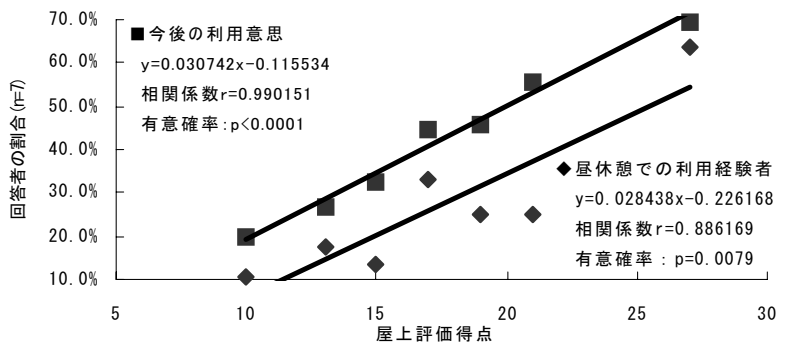

図-11 屋上評価得点と休䕀場所としての利用

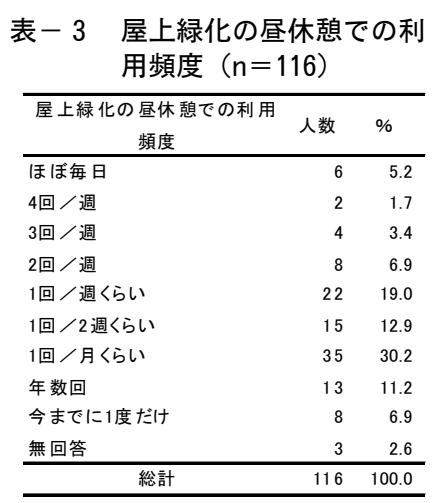

ている。今回の結果 でも, 気兼ねが無い という理由から，卜 イレ・化粧室で運動・ ストレッチをして過 ごす女性が多かった。 以上のことから, 散 歩や運動・ストレッ チに気兼ねなく利用 できる休㮩施設も必 要とされていると考 えられる。

（iv）休咊時間内の 屋上の利用

緑化された屋上で 昼休㮃時間を過ごし たことのある回答者 は23.0\%であった（図-10）。 表一 1 に示した評価得点の高 い屋上ほど利用経験者の割合 が有意に大であった（図-11)。 利用頻度は月に 1 度くらい （30.2\%）が最も多く（表一 3 ), 滞在時間は 5 分〜 10 分 が $42.2 \%$ と高い值を示した (表一 4 )。過ごし方は, 男性 は，ぼーっとする (58.2\%) が高い值を示したが，女性は 食べ物を食べる (64.3\%)，会話・雑 談 $(51.4 \%)$ が高い 值を示しており，自 席や食堂での男女別 の過ごし方と同様の 傾向を示した（図一 12)。一方，リフレッ シュ休䕀を過ごした ことのある回答者は $10.3 \%$ と少なかった (図-10)。それらの 回答者の利用頻度は

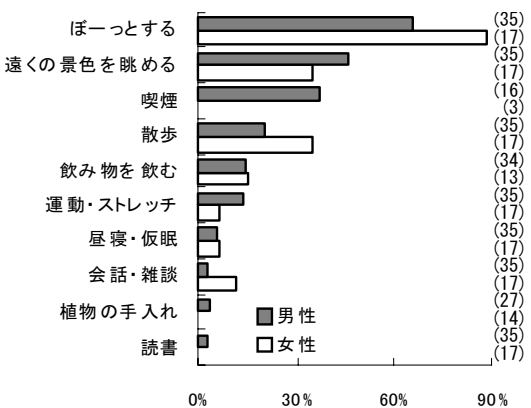

図-13 男女別屋上緑化でのリフレッシュ 休熄時間の過ごし方（ 3 つまで選 択）(図中（）内の数值は回答数）

月に 1 度くらい

（34.6\%）が最も多く（表－5）, 滞在時間は 5 分未満が $71.2 \%$ と 高い值を示し， 5 〜 10 分が $21.2 \%$ で，それ以上は $7.6 \%$ に満たな かった (図表省略)。滞在時間が昼休䕀時間よりも短くなったの は, リフレッシュ休䪹の時間の短かさに比例したものと推測でき る。過ごし方は, ぼーっとするが高い值を示し, 次いで遠くの景 色を眺める，喫煙，散歩などが高い值を示した（図－13）。利用 の理由は, 昼休㮩, リフレッシュ休媳ともに, 開放感があること (昼休㮩 $67.8 \%$, リフレッシュ休㮩 $82.7 \%$ ), 季節感を感じられ

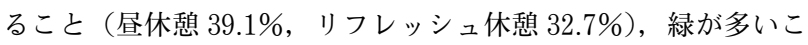
となどが高い值を示した（図一-14）。

望ましいリフレッシュルームの条件として, 開放感や居心地の よさ ${ }^{12)}$ が感じられ，適度な広さと程よい明るさ，外・遠くが見え ること ${ }^{13)}$ が確認されており，これらの条件を備えた屋上という空 間が，休㮩場所として支持されていると考えられた。

（v）今後の利用意思とその理由

今後, 休嚊場所として利用しょうと思う回答者の割合は, 


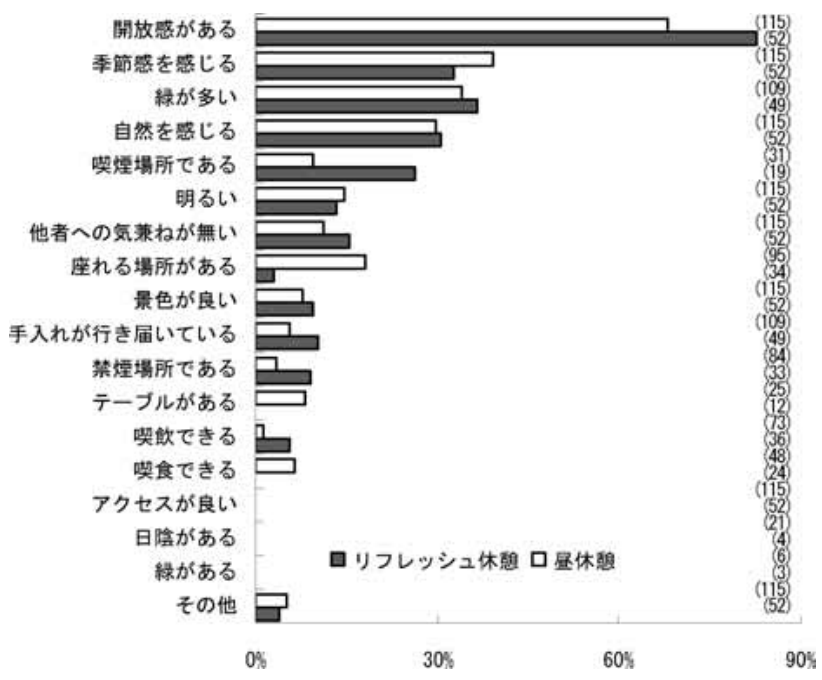

図ー14 昼及びリフレッシュ休㮩時間に緑化された屋上を利用す る理由（3つまで選択）（図中（ ）内の数値は回答数）

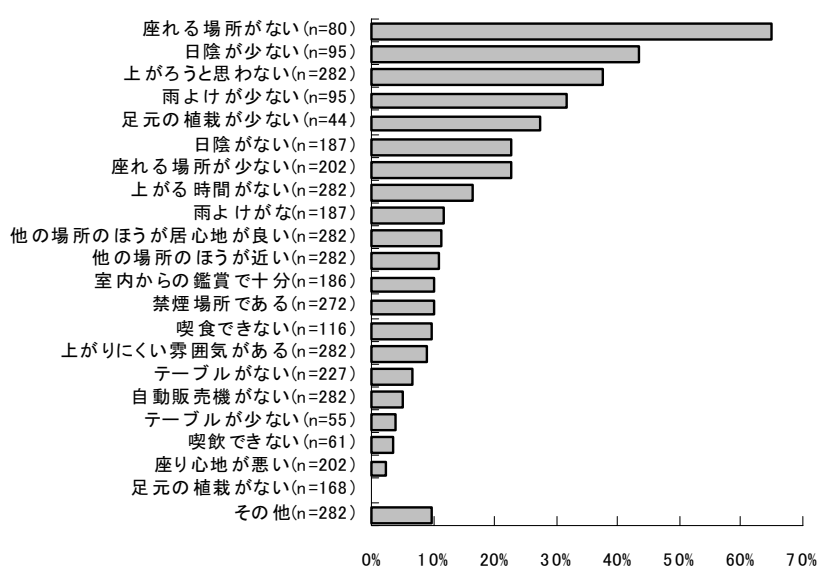

図一15緑化された屋上を休覟場所として利用しようと思わない 理由（ 3 つまで選択）

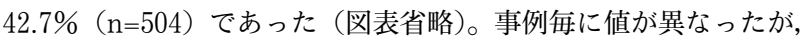
屋上評価得点と正の相関を示した（図－11）。利用しようと思う 理由は，休䕀での利用経験者が利用する理由と同様の傾向を示し， 開放感がある $(60.7 \%, \mathrm{n}=214)$, 緑が多い $(43.4 \%, \mathrm{n}=205)$, 自 然を感じる $(38.8 \%, n=214)$, 季節感を感じる $(35.5 \%, n=214)$ が高い值を示した（図表省略）。一方，「観賞用としての認識があ る」ため,「中に入っていいのかわからない」や「いっもきれい にし過ぎで近寄りにくい」,「イベントや PR を行ってほしい」な どの記述が多く, 利用したくても利用しづらいと感じている回答 者の存在が示唆された。

利用しようと思わない理由は，座れる場所が無い（65.0\%), 日陰が少ない（43.2\%）が，屋上まで上がろうと思わない （37.6\%）を上回る值を示した（図－15）。この結果より，座れる 場所や日陰を配置し休㮩場所としての環境を整えることにより, 利用拡大が可能となるものと推測された。

（3）屋上が緑化されていないオフィスビルでのアンケート調査 (i ）回答者の属性

配布した 92 部のうち, 80 部の有効回答を得た（有効回答率 87.0\%)。回答者の性別は, 男性 56.3\%, 女性 40.0\%であった (図表省略)。年代は，30 代が $32.5 \% ， 20$ 代と 40 代がそれぞれ $20.0 \%$ であった（図表省略）。所属部門は設計・技術が $27.5 \%$, 総 務・経理・人事が $22.5 \%$, 営業・販売が $15.0 \%$ となり（表－6 ）,
前述（3）の調査同様, 時間管理が 各自に任されている ${ }^{16)}$ 回答者が多かっ た。喫煙者は $18.8 \%$ ，非契煙者は $80.0 \%$ でった(図表省略)。

(ii ) 屋上の利用経験

屋上を訪れた経験のある回答者は 65.0\% であった（図表省略）。訪れ る理由は仕事が $30.0 \%$ と最も高い 值を示し，次いで社内行事に参加が 10.0\%となった（図－10）。特に,

\begin{tabular}{lrr} 
表 -6 & $\begin{array}{c}\text { 回答者の所属部門 } \\
(\mathrm{n}=80)\end{array}$ \\
\hline 回答者の所属部門 & 人数 & \multicolumn{1}{c}{$\%$} \\
\hline 総務·経理·人事 & 18 & 22.5 \\
営業·販売 & 12 & 15.0 \\
設計·技術 & 22 & 27.5 \\
企画·計画 & 5 & 6.3 \\
資材·調達·購買 & 4 & 5.0 \\
研究·開発 & 3 & 3.8 \\
その他 & 10 & 12.5 \\
無回答 & 6 & 7.5 \\
\hline \multicolumn{1}{c}{ 総計 } & 80 & 100.0 \\
\hline
\end{tabular}

屋上に神社が奉祀されている事例で高い值を示した。昼休慗時間 を過ごすのは $10.0 \%, \quad$ リレッシュ休䕀時間を過ごすのは $5.0 \%$ となり，緑化されていなくても，僅かながら休覕場所として利用 されていることが明らかになった。また，現在の屋上を休㴧場所 として利用しようと思う回答者は $27.5 \%$ あった (図表省略)。

(iii）屋上緑化の認知

緑化された屋上を訪問し知っているのは $42.5 \%$, 写真・映像 などを見たことがあり知っているのは $35.0 \%$ であった（図表省 略)。認知されている具体的な屋上緑化事例では, なんばパーク スや京都駅ビル，心斎橋そごうなど近年施工された百貨店や複合 施設などのアクセスしやすい事例が多く回答された（図表省略）。

（iv）屋上が緑化された場合の休慜場所としての利用意思と理由

屋上が緑化されれば休䡯場所として利用したいとの回答は 62.5\%であった。屋上緑化を初めて知った回答者（42.9\%）に比へ， 訪れたことのある回答者が高い值（70.6\%）を示した（図－16）。

利用しょうと思う回答者の理由では, 植栽により居心地の良い 空間になる $(70.0 \%)$, 自然を身近に感じる $(50.0 \%)$, 花により 季節感が感じられる (48.0\%) などが高い值を示し（図-17), 屋上に植物が植栽されることで得られる複数の効果が期待されて いることが明らかとなった。一方，利用しょうと思わない回答者 の理由は屋上まで上がろうと思わないが $66.7 \%$, 屋上まで上がる

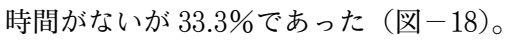

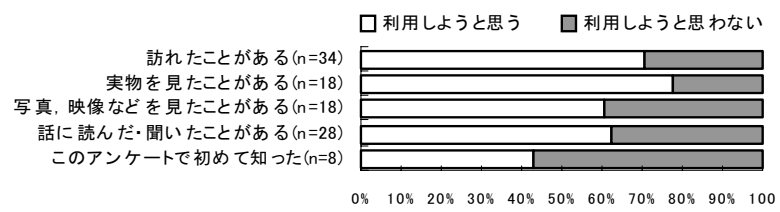

図-16 屋上緑化の認知度別屋上が緑化されれば休鄎場所として 利用しようと思う回答者の割合

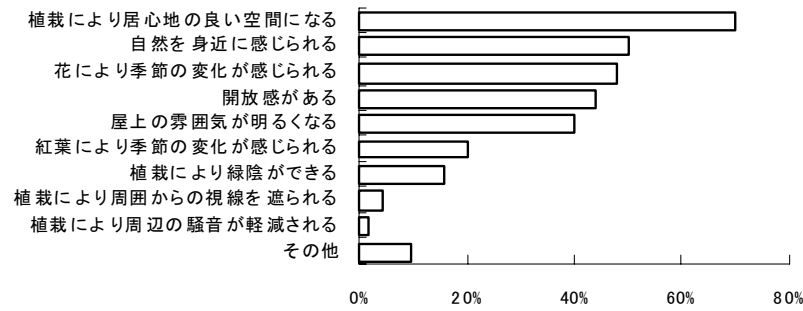

図-17 緑化された屋上を休您場所として利用しようと思う理由 $(n=50$, 複数回答)

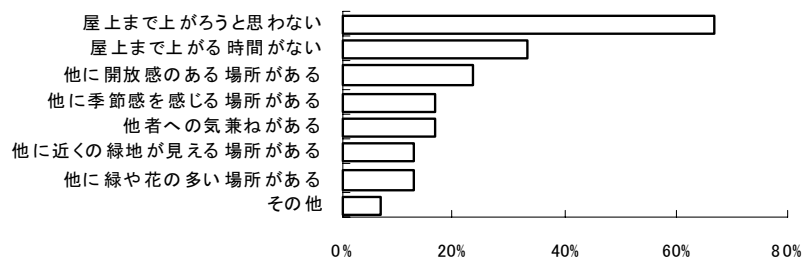

図ー18 緑化された屋上を休鄎場所として利用しようと思わない 理由（ $n=30$, 複数回答) 


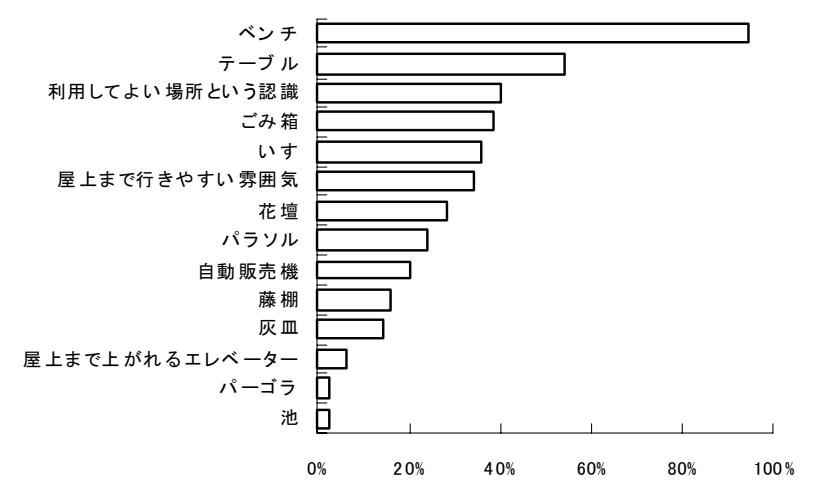

図ー19 緑化された屋上を休鄎場所として利用する際に必要と思 われる施設・設備など $(n=50$, 複数回答)

緑化された屋上の事例の内, 評価点が高いにも拘わらず昼休媳 での利用経験者の割合が低かった事例では「屋上面積が狭いため 利用に適さない」という指摘が多かった。「屋内から眺めるだけ でも癒される」という記述も多く, さらに, 利用しょうと思わな い理由として, 屋上まで上がろうと思わないが高い值を示した。 また，リフレッシュ休憩時間の屋上利用では, 短時間の滞在でぼーっ とする利用が多かったことから，屋上に広い面積を確保できない 場合は, 各階に観賞用の植栽を持つバルコニーを整備することで, より多くのオフィスワーカーに鄎いの場を提供できるものと考え られた。

（v）屋上を休㮩場所として利用する際に望ましい緑化と施設・ 設備のあり方

回答者 50 人の望む緑化された屋上のあり方を問う質問への回 答は, 屋上一面 (50.0\%) むしくは屋上の一角 $(34.0 \%)$ や屋上 の外周 (24.0\%) (図表省略) に芝や花の咲く植物や常緑の植物 （いずれも 67.3\%）（図表省略）など複数の植物（94.0\%）が植栽 され (図表省略)，さらにベンチ（94.0\%）とテーブル（54.0\%） が設置され, 利用して良い場所と認識されること（40.0\%）など であった（図一-19）。

人が座る頻度が高い広場であることの条件は, 単に座れる場所 が多いことであり ${ }^{20)}$, 一方, 休覟できる空間を考える場合, 視覚

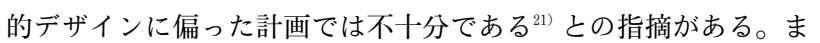
た, オフィスなどのリフレッシュルームには一定数の椅子が配置 されている ${ }^{13)}$ との報告むある。今回の調査で, 座れる場所の不 足が利用しようと思わない理由としてあげられたことからも，椅 子やベンチなどは緑化された屋上を休䕀場所として整備する際に 欠くことのできない要素であると考えられる。

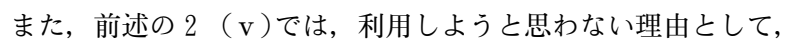
日陰が無いことが高い值を示したが, パラソルや藤棚を求める要 素とした回答は少なかった。日差しの強さは, 屋上で実際に体験

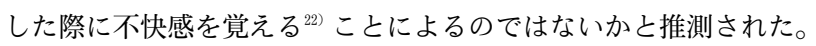
（vi）屋上が緑化された場合の休䅫場所としての過ごし方

ぼーっとする $(80.0 \%)$, 会話・雑談 $(58.0 \%)$, 飲み物を飲む （46.0\%）と食べる（32.0\%）などが高い值を示した（図表省略）。

\section{4. まとめ}

本研究では，緑化することにより屋上が㮩いと安らぎの空間と して利用される可能性を検討するため, オフィスビルの緑化され た屋上の休㽞場所としての機能を評価し，そのビルで働くオフィ スワーカーへのアンケート調查を実施した。その結果, 緑化され た屋上空間はその開放感と居心地の良さおよび自然や季節の変化 を身近に感じられることから，オフィスワーカーに休憩場所とし て期待されていることが明らかになった。

休㮃施設が整備され，休䕀場所としての評価が高い屋上空間ほ
ど，利用経験者が増加する傾向が見られた。したがって，オフィ スワーカーの䕀いの場とするには, 芝や花の咲く植物, 常緑の植 物など多様な植物が屋上一面に植栽され, 椅子やベンチなどの座 れる場所, 雨よけ, パラソルや藤棚など日差しを遮る設備および テーブルなどの休㮩施設の整備が必要であると考えられる。

また，「緑化された屋上に出ても良いかわからない」など迷い を示す自由記述が多く, 利用してよい場所であるとの認識が共有 されていない事例や，「時間がない」といった，休礊の取りにく さを指摘する記述も多かった。息抜きや気分転換のしやすさは, 仕事の能率に影響を与えることが指摘されている ${ }^{23)}$ 。オフィスワー

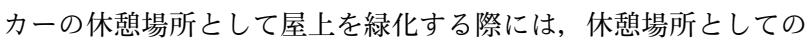
整備と同時に, 利用を促し, 休䕀時間に休䕀できる場所としての 雾囲気作りも重要であると考えられた。

\section{引用文献}

1 ）梅干野昆（2001）：屋上緑化之環境調整効果：日本緑化工学会誌 27 (2), 386-392

2 ) 財団法人都市緑化技術開発機構: 屋上・壁面緑化の推進に関する諸制 度 <http://www.greentech.or.jp/index.html> : 2006.3 .31 更新, 2007.9.21 参照

3 ) 京都府 : 温暖化対策条例 : 京都府例規集

<http://www.pref.kyoto.jp/reiki/reiki_honbun/a3001692001. $\mathrm{html}>, 2006.04 .01$ 更新, 2006.09.20 参照

4 ）下村孝（2005）：都市生活にとっての屋上・壁面緑化の意義とその普 及のための課題：都市問題研究 57(3), 50-65

5 ）佐々木ゆき・岡田準人・下村孝（2004）：緑化された屋上における影 観要素の違いが利用者の景観評価に及ぼす影響：日本緑化工学会誌 30(1), $157-162$

6 ）岡部衣羽子・須永修通・室恵子（2001）：屋上の緑化形態による心理 評価の違いに関する研究 一スライド評価実験による検討一：日本建 築学会大会学術講演梗概集(関東), 745-746

7 ) 長岡希・岡田準人・下村孝（2003）：ビデオ画像を用いた屋上緑化の 景観評価構造の解析：日本緑化工学会誌 29(1), 113-118

8 ) 労務行政研究所 (2006) : 労働安全衛生関係法令集 $<$ 平成 18 年度 版 $>$ : 労務行政, pp 2142

9 ）厚生労働省：事業者が講ずべき快適な職場環境の形成のための措置に 関する指針：法令等データベースシステムデータベースシステムー法 令検索一

$<$ http://wwwhourei.mhlw.go.jp/cgi-bin/t_docframe.cgi?MODE= hourei\&DMODE=CONTENTS\&SMODE=NORMAL\&KEYWORD= $\& \mathrm{EFSNO}=892>， 2006.07 .01$ 更新, 2006.09.20 参照

10）社団法人ニューオフィス推進協議会（2002）：平成 13 年度オフィス 実態調查報告書, pp 140

11）三和銀行（1998）：オフィスのアメニティー調査

12）大山能永・森川泰成・中村芳樹 (2003) : オフィスワーカーのリフレッ シュの現状について：日本建築学会技術報告集 17，269-274

13）大山能永（2005）：「リフレッシュルーム」の望ましさ測定方法の提 案：日本建築学会計画系論文集 596, 1-6

14）真鍋翼 - 柏原士郎・吉村英祐・横田隆司・飯田匡・生川慶一郎 （2003）：一般開放されている屋上緑化の利用実態に関する研究：日 本建築学会近畿支部 研究報告書, 317-320

15）東洋経済（2006）：会社四季報，2006 年 3 集 第 362 号, $2160 \mathrm{pp}$

16）佐藤真・下田充生・西田英一 (2000) : オフィスにおけるリフレッシュ メントの研究 : TASC REPORT No.5, 44-80

17）社団法人ニューオフィス推進協議会（2005）：オフィスワーカーのモ チベーションを上げる要因はこれだ！～仕事場を好きな場所にでき るか? ～: 社団法人ニューオフィス推進協議会, $71 \mathrm{pp}$

18）津村久美子・野村公江・前橋明・中永征太郎（1997）：VDT 作業後 の休愁之散歩による疲労感の回復効果について : 運動・健康教育研究 $6(2), 41-46$

19）柏原孝爾・室田真男・清水康敬（2000）：ワープロ作業時の安静及び 運動休想による心理的変化：2000 年電子情報通信学会総合大会, 207

20）ウイリアム.H. ホワイト・柿本照夫（1994）：都市という劇場：日本 経済新聞社, $402 \mathrm{pp}$

21）篠崎高志（2002）：都市の屋外公共空間における滞留行動に対する人 的要素の影響に関する研究 : ランドスケープ研究 65(5), 701-706

22) 村上大輔・下村孝 (2007) 緑化された屋上の異なる 3 地点における温 熱環境要素の測定と主観申告実験による快適性の検討：日本緑化工学 会誌 33(1), 152-157

23）浅沼龍一・宇治川正人（1990）：ワーカーの評価から見たオフィス計 画に関する研究 その 5 オフィスビル内のリフレッシュスペース： 日本建築学会大会学術講演梗概集 (中国), 605-606 